\title{
Simultaneous determination of brimonidine tartrate and timolol maleate by first derivative and ratio derivative spectroscopy
}

\begin{abstract}
New derivative, ratio derivative and multicomponent spectrophotometric methods have been established for the simultaneous determination of Brimonidine tartrate and Timolol maleate in pharmaceutical formulations using borate buffer $\mathrm{pH}$ 9.0. Linearity was observed $1-60 \mu \mathrm{g} / \mathrm{ml}$ for Timolol maleate and $1-40 \mu \mathrm{g} / \mathrm{ml}$ for Brimonidine tartrate. The three methods were validated and can be used for the determination of Brimonidine tartrate and Timolol maleate in eye drops.
\end{abstract}

Keywords: brimonidine tartrate, timolol maleate, spectrophotometry, first derivative method, ratio derivative spectra, multicomponent mode, validation
Volume 4 Issue 6 - 2017

\author{
Mukthinuthalapati Mathrusri Annapurna, \\ Malineni Sushmitha, Vellanki SV Sevyatha \\ Department of Pharmaceutical Analysis \& Quality Assurance, \\ GITAM University, India
}

Correspondence: Mukthinuthalapati Mathrusri Annapurna, GITAM Institute of Pharmacy, GITAM University, Rushikonda, Visakhapatnam-530045, India, Email mathrusri2000@yahoo.com

Received: April 26, 2017| Published: May II, 2017

\section{Introduction}

Brimonidine (CAS No. 59803-98-4) is chemically known as 5-bromo-N-(4,5-dihydro-1H-imidazol-2-yl)quinoxalin-6-amine with molecular formula, $\mathrm{C}_{11} \mathrm{H}_{10} \mathrm{BrN}_{5}$ and molecular weight $292.14 \mathrm{~g} / \mathrm{mol}$ Brimonidine (BRM) is freely soluble in water and soluble in methanol with pKa 7.78. Brimonidine is used to treat open-angle glaucoma or ocular hypertension. Brimonidine ${ }^{1}$ is indicated for the lowering of intraocular pressure in patients with open-angle glaucoma or ocular hypertension. Brimonidine is an $\alpha 2$ adrenergic agonist that acts by the activation of $\mathrm{G}$ protein-coupled receptor. This $\mathrm{G}$ protein-coupled receptor inhibits the activity of adenylate cyclase. The $\alpha 2$ agonist results in vasoconstriction of blood vessels and vasoconstriction reduces the aqueous humour flow. ${ }^{2}$

Timolol (CAS No. 26839-75-8) is chemically (S)-1-(tertbutylamino)-3-[(4-morpholin-4-yl-1,2,5-thiadiazol-3-yl)oxy]propan2-ol. Timolol (TML) can be used as an antihypertensive, antiarrhythmic, anti-angina, and anti-glaucoma agent. It has molecular formula, $\mathrm{C}_{13} \mathrm{H}_{24} \mathrm{~N}_{4} \mathrm{O}_{3} \mathrm{~S}$ and molecular weight $316.42 \mathrm{~g} / \mathrm{mol}$ (pKa 9.21). Timolol $^{3}$ is a beta-adrenergic antagonist and the levo isomer is the more active. Timolol is used for the treatment of migraine disorders, tremor. The combination of Brimonidine and Timolol have a rapid onset of action, with peak ocular hypotensive effect seen at two hours post-dosing for Brimonidine and one to two hours for Timolol. Very few spectrophotometric ${ }^{4-6}$ and liquid chromatographic methods ${ }^{7-8}$ are available in the literature for the simultaneous determination of BRM and TML. Generally, while doing the dissolution testing of drugs and their formulations different reagents ${ }^{9}$ of various $\mathrm{pH}$ are used and sometimes even first, second and fourth derivative spectroscopic methods are adopted in order to eliminate the interference from UV absorbing excipients during the analysis of formulations. ${ }^{10}$ The authors have proposed three spectrophotometric methods -first derivative, ratio derivative and multicomponent mode methods for the determination of BRM and TML in pharmaceutical formulations and the methods were validated. ${ }^{11}$

\section{Materials and methods}

\section{Chemicals and reagents}

The stock solutions of both Brimonidine tartrate and Timolo maleate were prepared in methanol and a series of solutions were prepared on dilution with borate buffer $(\mathrm{pH} 9.0)$ for the construction of calibration curve. The combination of Brimonidine tartrate and Timolol maleate is available with brand name Combigan (Allergen $\mathrm{Plc}$, India) as eye drops containing Brimonidine tartrate $0.2 \%$ and Timolol maleate $0.5 \%$.

\section{Instrumentation}

UV-1800 double beam UV-VIS spectrophotometer (Shimadzu) with a pair of $10 \mathrm{~mm}$ path length matched quartz cells is used for the study. All the sample solutions were scanned $200-400 \mathrm{~nm}$ with medium scanning speed.

\section{Procedure}

Three spectrophotometric methods-simultaneous first derivative method (D1) (Method I), ratio derivative method (Method II) and multi-component mode (Method III) were developed for the simultaneous determination of Timolol maleate and Brimonidine tartrate.

Method I: simultaneous first derivative method (D1): The individual zero order absorption spectra of Timolol maleate and Brimonidine tartrate were converted in to their first order derivative spectra with the help of inbuilt software. The first order derivative spectra of TML shows zero crossing points at 251.5, 295.37 and $366.38 \mathrm{~nm}$ and that of BRM at 205.5, 234.9, 257, 308.4 and $357.5 \mathrm{~nm}$. TML can be quantified from the maxima observed at $257 \mathrm{~nm}$ (zero crossing point of BRM) whereas BRM can be quantified from the maxima observed at $251.5 \mathrm{~nm}$ (zero crossing point of TML).

Method II: ratio derivative method: In ratio derivative method aliquots of TML equivalent to $1-60 \mu \mathrm{g} / \mathrm{ml}$ were accurately transferred to $10 \mathrm{ml}$ volumetric flask from stock solution $(1000 \mu \mathrm{g} / \mathrm{ml})$ and the volume is adjusted with borate buffer $\mathrm{pH}$ 9.0. The absorption spectra of the prepared solution were scanned and recorded in the range of $200-400 \mathrm{~nm}$. These solutions were added with $10 \mu \mathrm{g} / \mathrm{ml}$ of BRM with the help of inbuilt software. The obtained spectrum is converted into first derivative with the help of the inbuilt software. The maxima of the spectrum was found to be $280 \mathrm{~nm}$ and minima was found to be $312 \mathrm{~nm}$, then the amplitude was calculated. The calibration curve was constructed with amplitude on y-axis against the concentrations. Similarly, TML solutions were subtracted with $10 \mu \mathrm{g} / \mathrm{ml}$ of BRM. The maxima of the spectrum was found to be $265.5 \mathrm{~nm}$ and minima 
was found to be $312.5 \mathrm{~nm}$, then the amplitude was calculated. In the same way, the solutions were multiplied with $10 \mu \mathrm{g} / \mathrm{ml}$ of BRM. The maxima of the spectrum was found to be $278 \mathrm{~nm}$ and minima was found to be $293 \mathrm{~nm}$, then the amplitude was calculated. The solutions were divided with $40 \mu \mathrm{g} / \mathrm{ml}$ of BRM. The maxima of the spectrum was found to be $292 \mathrm{~nm}$ and minima was found to be $313 \mathrm{~nm}$, then the amplitude was calculated.

In the same way, different concentrations of BRM in the range of $1-40 \mu \mathrm{g} / \mathrm{ml}$ were scanned and recorded in the range of $200-400 \mathrm{~nm}$. These solutions were added with $10 \mu \mathrm{g} / \mathrm{ml}$ of TML with the help of inbuilt software. The obtained spectrum is converted into first derivative with the help of the inbuilt software. The maxima of the spectrum was found to be $249 \mathrm{~nm}$ and minima was found to be $264.5 \mathrm{~nm}$, then the amplitude was calculated. The calibration curve was constructed with amplitude on y-axis against the concentrations. Similarly, BRM solutions were subtracted with $10 \mu \mathrm{g} / \mathrm{ml}$ of TML. The maxima of the spectrum was found to be $249 \mathrm{~nm}$ and minima was found to be $265 \mathrm{~nm}$, then the amplitude was calculated. In the same way, the solutions were multiplied with $10 \mu \mathrm{g} / \mathrm{ml}$ of TML. The maxima of the spectrum was found to be $277 \mathrm{~nm}$ and minima was found to be $293 \mathrm{~nm}$, then the amplitude was calculated. The solutions were divided with $50 \mu \mathrm{g} / \mathrm{ml}$ of BRM. The maxima of the spectrum was found to be $247 \mathrm{~nm}$ and minima was found to be $262 \mathrm{~nm}$, then the amplitude was calculated. The obtained spectrum is converted into first derivative with the help of the inbuilt software. Calibration curves for both TML and BRM were constructed by plotting the amplitude values on y-axis against their corresponding concentrations.

Method III: multi-component mode: In this multi-component mode method TML and BRM were mixed in different ratios $(>3)$ and the instrument scan $(200-400 \mathrm{~nm})$ the solutions with the inbuilt software and finally the concentration of the individual components i.e. TML and BRM were given directly for the unknown combination of solutions (or formulation solutions). For the present study seven standard solutions containing Timolol maleate and Brimonidine tartrate were prepared in 1:10, 5:15, 10:20, 20:10, 15:30, 30:40 and 40:60 ratio Borate buffer ( $\mathrm{pH} 9.0)$ and scanned in multi-component mode.

\section{Method validation}

Linearity: $1-60 \mu \mathrm{g} / \mathrm{ml}$ Timolol maleate and $1-40 \mu \mathrm{g} / \mathrm{ml}$ Brimonidine tartrate solutions were prepared from the stock solutions separately and scanned against the reagent blank i.e. borate buffer $\mathrm{pH} 9.0$ and the first derivative is done with the help of inbuilt software and the absorbance values were calculated at the selected wavelengths for both the methods. A graph was drawn by taking the concentration of the drug solution on the x-axis and the corresponding absorbance values on the $y$-axis at the selected wavelengths.

Precision and accuracy: The intra-day and inter-day precision studies were performed at three different concentration levels $(10,20$ and $40 \mu \mathrm{g} / \mathrm{mL}$ ) and the $\% \mathrm{RSD}$ was calculated. Accuracy studies were carried out for both the methods 1 and $2(80 \%, 100 \%$, and $120 \%)$ and the $\%$ recovery was calculated.

Assay of brimonidine tartrate and timolol maleate in marketed formulations: The combination of Timolol maleate and Brimonidine tartrate is available with brand name Combigan (Allergen Plc, India) as eye drops containing Brimonidine tartrate $0.2 \%$ and Timolol maleate $0.5 \%$. The eye drops preparation was procured from local pharmacy store and extracted with methanol and then assayed after dilution with borate buffer with the three methods.

Table I Precision studies of timolol maleate and brimonidine tartrate

\begin{tabular}{|c|c|c|c|c|c|c|c|c|c|c|c|}
\hline \multirow{3}{*}{ Drug } & \multirow{3}{*}{$\begin{array}{l}\text { Conc } \\
(\mu g / \mathrm{ml})\end{array}$} & \multirow{2}{*}{\multicolumn{5}{|c|}{$\begin{array}{l}\text { Intra-Day Precision } \\
* \text { Conc. Obtained }(\mu \mathrm{g} / \mathrm{ml}) \pm \mathrm{SD}(\text { RSD }) \\
{[* \% \text { Recovery }]}\end{array}$}} & \multirow{2}{*}{\multicolumn{5}{|c|}{$\begin{array}{l}\text { Inter-Day Precision } \\
\text { *Conc. Obtained }(\mu \mathrm{g} / \mathrm{ml}) \pm \mathrm{SD}(\mathrm{RSD}) \\
{[\% \% \text { Recovery] }}\end{array}$}} \\
\hline & & & & & & & & & & & \\
\hline & & Method I & $\begin{array}{l}\text { Method II } \\
\text { A }\end{array}$ & B & C & $D$ & Method I & $\begin{array}{l}\text { Method II } \\
\text { A }\end{array}$ & B & C & D \\
\hline \multirow{3}{*}{ TML } & 10 & $\begin{array}{l}9.98 \pm 0.02 \\
(0.24)[99.8]\end{array}$ & $\begin{array}{l}9.93 \pm 0.02 \\
(0.18)[99.3]\end{array}$ & $\begin{array}{c}9.94 \pm 0.02 \\
](0.25)[99.4]\end{array}$ & $\begin{array}{l}9.91 \pm 0.02 \\
(0.29)[99.1]\end{array}$ & $\begin{array}{l}9.95 \pm 0.04 \\
(0.39)[99.5]\end{array}$ & $\begin{array}{l}9.91 \pm 0.10 \\
(0.99)[99.1]\end{array}$ & $\begin{array}{l}9.94 \pm 0.06 \\
(0.65)[99.4]\end{array}$ & $\begin{array}{l}9.92 \pm 0.05 \\
(0.5 I)[99.2]\end{array}$ & $\begin{array}{l}9.94 \pm 0.09 \\
(0.99)[99.4]\end{array}$ & $\begin{array}{l}9.96 \pm 0.13 \\
(1.37)[99.6]\end{array}$ \\
\hline & 20 & $\begin{array}{l}19.9 \pm 0.14 \\
(0.72)[99.6]\end{array}$ & $\begin{array}{l}19.86 \pm 0.3 \\
(0.54)[99.3\end{array}$ & $\begin{array}{c}19.91 \pm 0.05 \\
](0.29)[99.5]\end{array}$ & $\begin{array}{l}19.89 \pm 0.08 \\
(0.44)[99.4]\end{array}$ & $\begin{array}{l}19.83 \pm 0.10 \\
(0.59)[99.1]\end{array}$ & $\begin{array}{l}19.92 \pm 0.20 \\
(1.05)[99.6]\end{array}$ & $\begin{array}{l}19.82 \pm 0.19 \\
(0.98)[99.2]\end{array}$ & $\begin{array}{l}19.92 \pm 0.3 \\
(0.84)[99.6]\end{array}$ & $\begin{array}{l}19.86 \pm 0.24 \\
(1.24)[99.3]\end{array}$ & $\begin{array}{l}19.85 \pm 0.22 \\
(1.14)[99.2]\end{array}$ \\
\hline & 40 & $\begin{array}{l}39.1 \pm 0.31 \\
(0.09)[97.7]\end{array}$ & $\begin{array}{l}38.9 \pm 0.31 \\
(0.81)[97.8]\end{array}$ & $\begin{array}{c}39.2 \pm 0.31 \\
3(0.14)[98.0]\end{array}$ & $\begin{array}{l}39.4 \pm .31 \\
(0.12)[98.5]\end{array}$ & $\begin{array}{l}39.1 \pm 0.31 \\
(0.09)[97.7]\end{array}$ & $\begin{array}{l}39.5 \pm 0.37 \\
(0.94)[98.4]\end{array}$ & $\begin{array}{l}39.5 \pm 0.47 \\
(1.20)[98.7]\end{array}$ & $\begin{array}{l}39.4 \pm 0.35 \\
(0.91)[98.5]\end{array}$ & $\begin{array}{l}39.5 \pm 0.37 \\
(0.96)[98.7]\end{array}$ & $\begin{array}{l}39.7 \pm 0.49 \\
(1.24)[99.2]\end{array}$ \\
\hline \multirow{3}{*}{ BRM } & 10 & $\begin{array}{l}9.95 \pm 0.04 \\
(0.39)[99.5]\end{array}$ & $\begin{array}{l}9.92 \pm 0.02 \\
(0.21)[99.2\end{array}$ & $\begin{array}{c}9.94 \pm 0.02 \\
](0.19)[99.4]\end{array}$ & $\begin{array}{l}9.98 \pm 0.02 \\
(0.24)[99.8]\end{array}$ & $\begin{array}{l}9.9 I \pm 0.05 \\
(0.5 \mathrm{I})[99.1]\end{array}$ & $\begin{array}{l}9.96 \pm 0.13 \\
(1.37)[99.6]\end{array}$ & $\begin{array}{l}9.93 \pm 0.09 \\
(0.98)[99.3]\end{array}$ & $\begin{array}{l}9.93 \pm 0.08 \\
(0.8 I)[99.3]\end{array}$ & $\begin{array}{l}9.91 \pm 0.10 \\
(0.99)[99.1]\end{array}$ & $\begin{array}{l}9.94 \pm 0.12 \\
(1.21)[99.4]\end{array}$ \\
\hline & 20 & $\begin{array}{l}19.8 \pm 0.11 \\
(0.59)[99.1]\end{array}$ & $\begin{array}{l}19.8 \pm 0.10 \\
(0.52)[99.2\end{array}$ & $\begin{array}{l}19.8 \pm 0.08 \\
{[0.40)[99.3]}\end{array}$ & $\begin{array}{l}19.9 \pm 0.04 \\
(0.22)[99.5]\end{array}$ & $\begin{array}{l}19.8 \pm 0.02 \\
(0.12)[99.4]\end{array}$ & $\begin{array}{l}19.9 \pm 0.20 \\
(1.05)[99.4]\end{array}$ & $\begin{array}{l}19.7 \pm 0.21 \\
(1.10)[98.9]\end{array}$ & $\begin{array}{l}19.9 \pm 0.14 \\
(0.72)[99.6]\end{array}$ & $\begin{array}{l}19.9 \pm \\
0.18(0.94) \\
{[99.8]}\end{array}$ & $\begin{array}{l}19.9 \pm 0.20 \\
(1.05)[99.6]\end{array}$ \\
\hline & 40 & $\begin{array}{l}39.2 \pm 0.31 \\
(0.14)[98.0]\end{array}$ & $\begin{array}{l}39.4 \pm 0.26 \\
(0.67)[98.5\end{array}$ & $\begin{array}{c}39.1 \pm 0.31 \\
](0.09)[97.7]\end{array}$ & $\begin{array}{l}39.5 \pm 0.37 \\
(0.96)[98.7]\end{array}$ & $\begin{array}{l}39.2 \pm 0.31 \\
(0.14)[98.0]\end{array}$ & $\begin{array}{l}39.4 \pm 0.35 \\
(0.91)[98.5]\end{array}$ & $\begin{array}{l}39.2 \pm 0.31 \\
(0.8 I)[98.0]\end{array}$ & $\begin{array}{l}39.7 \pm 0.49 \\
(1.24)[99.2]\end{array}$ & $\begin{array}{l}39.5 \pm 0.47 \\
(1.20)[98.7]\end{array}$ & $\begin{array}{l}39.4 \pm 0.35 \\
(0.91)[98.5]\end{array}$ \\
\hline
\end{tabular}

*Mean of three replicates.

\section{Results and discussion}

Three new spectrophotometric methods, simultaneous first derivative method (D1) (Method I), ratio derivative method (Method II) and multi-component mode (Method III) were proposed and validated for the simultaneous determination of Brimonidine and Timolol in borate buffer $\mathrm{pH}$ 9.0.

\section{Method I: simultaneous first derivative method (D1)}

The overlay first order derivative spectrum of Timolol maleate and Brimonidine tartrate was shown in Figure 1. Linearity was observed over the concentration range $1-60 \mu \mathrm{g} / \mathrm{mL}$ and $1-40 \mu \mathrm{g} / \mathrm{mL}$ for TML and $\mathrm{BRM}$ respectively. The linear regression equations were found to be $\mathrm{y}$ $=0.0014 \mathrm{x}+0.0008\left(\mathrm{R}^{2}=0.9991\right)$ and $\mathrm{y}=0.0054 \mathrm{x}+0.0002\left(\mathrm{R}^{2}=0.9997\right)$ 
in method A and B respectively. A graph was drawn by taking the drug concentration (TML or BRM) on the $\mathrm{x}$-axis and the corresponding derivative absorbance on the $\mathrm{y}$-axis and a straight line graph was obtained (Figure 2A and 2B).

\section{Method II: ratio derivative method}

The overlay ratio derivative spectra of Timolol maleate and Brimonidine tartrate was shown in Figure 3 \& 4. In Figure 3A-3C TML is added, subtracted and multiplied with $10 \mu \mathrm{g} / \mathrm{ml}$ of BRM whereas in Figure 3D TML is divised with $40 \mu \mathrm{g} / \mathrm{ml}$ of BRM. Linearity was observed over the concentration range $1-60 \mu \mathrm{g} / \mathrm{mL}$ and $1-40 \mu \mathrm{g} / \mathrm{mL}$ for TML and BRM for each method respectively. The linear regression equations of Timolol maleate were found to be $y=0.0013 x-0.0013$ $\left(\mathrm{R}^{2}=0.9991\right), \mathrm{y}=0.0016 \mathrm{x}-0.0002\left(\mathrm{R}^{2}=0.9991\right), \mathrm{y}=0.0003 \mathrm{x}+0.0002$
$\left(\mathrm{R}^{2}=0.9994\right)$ and $\mathrm{y}=0.0037 \mathrm{x}+0.001\left(\mathrm{R}^{2}=0.9994\right)$ in method $\mathrm{A}, \mathrm{B}, \mathrm{C}$ and $\mathrm{D}$ respectively. The linear regression equations of Brimonidine tartrate were found to be $y=0.005 x-0.0015\left(R^{2}=0.9996\right), y=0.0052 x+0.0038$ $\left(\mathrm{R}^{2}=0.9992\right), \mathrm{y}=0.0003 \mathrm{x}-0.0005\left(\mathrm{R}^{2}=0.9998\right)$ and $\mathrm{y}=0.0327 \mathrm{x}-0.0004$ $\left(\mathrm{R}^{2}=0.9993\right)$ in method $\mathrm{A}, \mathrm{B}, \mathrm{C}$ and $\mathrm{D}$ respectively. A graph was drawn by taking the drug concentration (TML or BRM) on the $\mathrm{x}$-axis and the corresponding derivative absorbance on the y-axis and a straight line graph was obtained (Figure 5A-5D \& 6A-6D).

\section{Method III: multi-component mode}

In multi-component mode method TML and BRM were directly determined from the inbuilt loaded software. The eyedrop formulation (20:50) has shown BRM: TML as 20.319: 49.236 indicating that BRM is $101.59 \%$ and TML as $98.47 \%$.

Table 2 Accuracy studies of timolol maleate and brimonidine tartrate

\begin{tabular}{|c|c|c|c|c|c|c|c|}
\hline \multirow[t]{2}{*}{ Drugs } & \multirow{2}{*}{$\begin{array}{l}\text { Spiked } \\
\text { Conc }(\mu \mathrm{g} / \mathrm{ml})\end{array}$} & \multirow{2}{*}{$\begin{array}{l}\text { Total } \\
\text { Conc. }(\mu g / m l)\end{array}$} & \multirow{2}{*}{$\begin{array}{l}\text { Method I } \\
\text { \%*Recovery (\%RSD) }\end{array}$} & $\begin{array}{l}\text { Method II } \\
\text { A }\end{array}$ & B & C & D \\
\hline & & & & \%*Recovery (\%RSD) & \%*Recovery (\%RSD) & \%*Recovery (\%RSD) & \%*Recovery (\%RSD) \\
\hline \multirow{4}{*}{ TML } & $8(80 \%)$ & 18 & $99.66(0.92)$ & $99.7(0.92)$ & $99.1(0.84)$ & $98.72(0.91)$ & $99.7(0.37)$ \\
\hline & $10(100 \%)$ & 20 & $99.19(1.07)$ & $99.1(1.01)$ & $99.5(0.93)$ & $99.01(0.7 I)$ & $99.4(0.64)$ \\
\hline & $12(120 \%)$ & 22 & $98.54(0.91)$ & $99.4(0.84)$ & $99.2(1.21)$ & $99.21(1.18)$ & $99.7(0.93)$ \\
\hline & $8(80 \%)$ & 18 & $98.88(1.16)$ & $98.8(1.04)$ & $98.8(0.42)$ & $99.20(0.37)$ & $99.2(0.18)$ \\
\hline \multirow{2}{*}{ BRM } & $10(100 \%)$ & 20 & $98.6 \mathrm{I}(0.98)$ & $99.5(1.25)$ & $99.4(0.67)$ & $99.59(0.19)$ & $98.4(0.48)$ \\
\hline & $12(120 \%)$ & 22 & $99.42(0.88)$ & $98.9(0.97)$ & $99.8(0.28)$ & $98.10(0.67)$ & $98.6(0.8 \mathrm{I})$ \\
\hline
\end{tabular}

*Mean of three replicates.

Table 3 Assay of timolol maleate and brimonidine tartrate

\begin{tabular}{lllllll}
\hline & & \multicolumn{2}{c}{ Label } & \multicolumn{2}{c}{$*$ Amount Found } & \multicolumn{2}{c}{ Recovery } \\
Formulation Brand & Drug & Claim $\mathbf{( m g )}$ & Method I & Method II & Method I & Method II \\
\hline \multirow{2}{*}{ Combigan Eye drops } & Timolol & 5 & 4.96 & 4.97 & 99.2 \\
& Brimonidine & 2 & 1.97 & 1.98 & 99.4 \\
\hline
\end{tabular}

\section{Precision and accuracy}

The precision and accuracy studies were performed and the results were given in Table $1 \& 2$. The percentage RSD was found to be less than $2 \%$ indicating that the methods are precise and accurate. The assay of marketed formulation was found to be 98.50-99.40 Table 3).

\section{Conclusion}

The three spectrophotometric methods is simple, precise and accurate for the simultaneous determination of Timolol maleate and Brimonidine tartrate in pharmaceutical formulations successfully.

\section{Acknowledgements}

The authors are grateful to M/s GITAM University, Visakhapatnam for providing the research facilities. There is no conflict of interest.

\section{Conflicts of Interset}

None.

\section{References}

1. Merck Research Laboratories Division of Merck and Co., Inc. (14 $4^{\text {th }}$ edn), The Merck Index, Whitehouse Station, New Jersey, USA, 2006. p. 225.

2. Toris C, Camras C, Yablonski M. Acute versus chronic effects of Brimonidine on aqueous humor dynamics in ocular hypertensive patients. American journal of ophthalmology. 1999;128(1):8-14.

3. Merck Research Laboratories Division of Merck and Co., Inc. (14th edn), The Merck Index, Whitehouse Station, NJ, USA, 2006. p. 1623.
4. Heta HD, Anandkumari DC. Three simple validated UV spectrophotometric methods for the simultaneous estimation of Timolol and Brimonidine and their comparison using ANOVA. International Journal of Pharmaceutical Research \& Analysis. 2014;4(3):168-177.

5. Vinayaka DG, Satishkumar SA, Manzoor A. Simultaneous determination of Brimonidine and Timolol in combined pharmaceutical dosage form using two different green spectrophotometric methods. Journal of Harmonized Research in Pharmacy. 2015;4(1):52-59.

6. Hiral SP, Hemant MP. Simultaneous determination of Brimonidine and Timolol in combined pharmaceutical dosage form using two different green spectrophotometric methods. World Journal of Pharmacy and Pharmaceutical Sciences. 2014;3(3):1330-1340.

7. Arun P, Murugesan SK, Nanjaian M. Simultaneous estimation of Brimonidine and Timolol in nanoparticles formulation by RP-HPLC. International Journal of Recent Advances in Pharmaceutical Research. 2011;3:31-36.

8. Abdullah AE, Hani MH, Lobna MA. Development and validation of HPLC method for simultaneous estimation of Brimonidine and Timolol in bulk and pharmaceutical dosage form. Journal Chromatograph Separation Technique. 2014;5(3).

9. Lei W, Mandana A. Second-derivative UV spectrometric determination of simvastatin in its tablet dosage form. Journal of Pharmaceutical and Biomedical Analysis. 2000;21(6):1243-1248.

10. Yinhe T, Xiaoqing S, Lulu Z, et al. Development and validation of dissolution testings in acidic media for rabeprazole sodium delayedrelease capsules. Drug Dev Ind Pharm. 2016;42(10):1669-1677.

11. ICH Validation of analytical procedures: Text and methodology $Q 2$ (R1). International Conference on Harmonization, 2005. p. 1-17. 